\title{
PEREMPUAN INDONESIA TAHUN 1970-an DAN 1980-an DALAM CERITA PENDEK KARYA DJUMRI OBENG
}

\author{
Aquari Mustikawati \\ Kantor Bahasa Kalimantan Timur \\ sunburn_4s@yahoo.co.id
}

\begin{abstract}
How to cite (in APA Style): Mustikawati, A. (2018). Perempuan indonesia tahun 1970-an dan 1980-an dalam cerita pendek karya Djumri Obeng. Jurnal Pendidikan Babasa dan Sastra, 18(2), doi:10.17509/bs_jpbsp.v18i2.15515
\end{abstract}

Article History: Received (25 June 2018); Revised (18 September 2018); Accepted (01 October 2018). Journal homepage: http:// ejournal.upi.edu./index.php/BS_JPBSP

\begin{abstract}
This study aims to illustrate the image of Indonesian women in the 1970s and 1980s in three short stories by Djumri Obeng, "Bidadari di Tengah Hutan", "Anah", and "Peni". The three short stories represent the picture of the circumstances of women in those days. The problem focused on this research is how the image of Indonesian women in the 1970s and 1980s and the authors' views on the marginalization of women in those days. Descriptive qualitative method is used to solve the problems, by using positivism and phenomenological paradigm to understand human behavior and their frame of mind. By using the theory of focalization, this paper analyzes the views of society at that time which is depicted in focalizator figures in the three short stories. The results showed that women in the 1970s and 1980s experienced marginalization through three spaces, namely social, economic, and stereotyped. It can be concluded that women with low educational and economic levels during that period were targeted for insolvency because they lacked fighting power.
\end{abstract}

Keywords: women, marginal, focalization, social, economy, stereotypes

\section{INDONESIAN WOMEN OF 1970 S AND 1980 IN DJUMRI OBENG'S SHORT STORIES}

\begin{abstract}
Abstrak: Penelitian ini bertujuan menggambarkan citra perempuan Indonesia tahun 1970-an dan 1980an dalam tiga cerita pendek karya Djumri Obeng, yaitu "Bidadari di Tengah Hutan", Anah", dan Peni”. Ketiga cerita pendek tersebut mewakili gambaran keadaaan perempuan pada masa tersebut. Masalah yang difokuskan dalam penelitian ini adalah bagaimana citra perempuan Indonesia tahun 1970-an dan 1980-an dan pandangan pengarang terhadap marginalisasai perempuan pada masa tersebut. Untuk memecahkan masalah dan mencapai tujuan digunakan metode kualitatif yang bersifat deskriptif, yaitu dengan menggunakan paradigma positivisme dan fenomenologis untuk memahami perilaku manusia dan kerangka berpikir mereka. Dengan menggunakan teori fokalisasi, tulisan ini menganalisis pandangan masyarakat pada masa itu yang tergambar dalam fokalisator tokoh-tokoh dalam ketiga cerita pendek tersebut. Hasil penelitian menunjukkan bahwa perempuan pada tahun 1970-an dan 1980-an mengalami marginalisasi melalui tiga ruang, yaitu sosial, ekonomi, dan stereotip. Dari hasil penelitian dapat disimpulkan bahwa perempuan dengan tingkat pendidikan dan ekonomi rendah pada masa tersebut adalah sasaran pemarginalan karena tidak memiliki kekuatan melawan.
\end{abstract}

Kata kunci: perempuan, marginal, fokalisasi, sosial, ekonomi, stereotip 


\section{PENDAHULUAN}

Dalam suatu karya sastra, penokohan memiliki peranan yang sangat penting untuk membantu terwujudnya gagasan cerita yang ingin disampaikan oleh pengarang. Penokohan yang kuat dapat menghidupkan cerita. Penokohan seringkali didefinisikan sebagai cara pengarang dalam memberikan sifat-sifat yang ada pada diri tokoh dalam sebuah cerita. Melalui penokohan dapat diketahui karakter dan sifat tokoh yang disematkan pengarang dalam karyanya. Bahkan, melalui penokohan dapat juga diketahui pemikiran pengarang terhadap suatu permasalahan. Untuk menguak karakter tokoh cerita dan pemikiran atau gagasan pengarang melalui penokohan dalam ceritanya, penulis menggunakan teori komunikasi fokalisasi dan feminisme.

Fokalisasi dikenal juga dengan sudut pandang, kancah perhatian, perspektif cerita, dan masih banyak lagi. Istilah ini pertama kali dikemukakan Gerard Genette dalam bukunya Narrative Discourse (1972) untuk menjelaskan sudut pandang para narator dalam karya sastra. Teori fokalisasi sebagai bagian dari teori komunikasi digunakan untuk menjawab paradigma modern bahwa karya sastra dapat diapresiasi melalui pencerita fiksional yang terdapat dalam karya sastra dengan mengabaikan pengarang sebagai penulis utama. Hal itu berarti bahwa para narator dalam karya sastra berperan dalam menentukan pemahaman pembaca dan kritikus terhadap suatu karya sastra. Fokalisasi menurut Luxembug, Bal, \& Westteijn (1991,p.117) dibagi menjadi dua jenis, yaitu fokalisasi intern dan fokalisasi ekstern. Fokalisasi intern berupa sudut pandang yang berasal dari dalam cerita, terutama tokoh-tokoh dalam cerita. Fokalisasi intern dapat berupa percakapan langsung, ungkapan tokoh, atau ungkapan seorang penutur. Fokalisasi intern berfungsi untuk memperkenalkan tokoh melalui cara tokoh itu bergaul dengan perasaannya. Fokalisasi ekstern adalah sudut pandang yang berasal dari luar cerita. Fokalisasi ini disebut juga sebagai sudut pandang menyeluruh karena sudut pandang tersebut melihat keseluruhan cerita. Fokus pandang dalam fokalisasi ekstern cerita berkaitan dengan pencerita atau pun teks pencerita. Sementara itu, Ratna (2008,p. 316) menjelaskan bahwa fokalisasi dapat dilakukan oleh seorang tokoh dalam cerita atau juru cerita yang menceritakan sesuatu melalui perspektif mereka sebagai fokalisator.

Teori sastra feminis, yaitu salah satu interdisipliner kajian perempuan, yang meneliti bagaimana kaum perempuan ditampilkan dan bagaimana teks tersebut membahas hubungan gender dan perbedaan jenis kelamin. Kritik sastra feminis dalam tulisan ini dioperasikan dengan memfokuskan pada pandangan tokoh-tokoh pembawa budaya patriarki. Melalui tokoh-tersebut yang dianggap sebagai fokalisator dapat diketahui perspektif mereka tentang gender dan patriarki. Beberapa tokoh dalam ketiga cerita pendek tersebut terdapat faktor negatif yang mendukung pemarginalan perempuan. Selain pemarginalan, fokalisator faktor negatif dalam cerita-cerita pendek kaya Djumri Obeng juga memosisikan perempuan sebagai subordinat dan melakukan kekerasan terhadap perempuan. Tindakan tersebut digolongkan dalam perlakuan ketidakadilan gender yang memosisikan satu golongan lebih tinggi kedudukannya dari golongan lain, yaitu perempuan miskin dan tidak berpendidikan(Murniati, 2004a,p. 78).

Masa kreatif penulisan Djumri Obeng tahun 1970-an sampai dengan 1980-an. Gaya penulisan dan penceritaannya dipengaruhi gaya pada masa itu, yaitu mulainya gaya penceritaan yang bebas bereksperimen dalam penggunaan bahasa dan tema. Setelah peristiwa G30S/PKI, sastrawan seakan menemukan pintu kebebasan dalam berkarya. Mereka terbebas dalam mengekspresikan diri mereka tanpa 
pengaruh politik atau menjadi alat propaganda politik. Kebebasan secara psikologis tersebut mampu memunculkan beragam karya eksperimental sehingga tidaklah mengherankan apabila tema-tema yang terdapat dalam karya pada masa tersebut sangat beragam. Demikian pula dengan pemilihan kata-kata juga sangat beragam pada setiap pengarang. Kebebasan di era tersebut memengaruhi Djumri Obeng dengan gaya tersendiri, yaitu penggunaan bahasa yang cukup vulgar dan mengandung tema-tema tragis. Tema-tema dalam karya Djumri Obeng, biasanya didominasi oleh warna lokal kedaerahan dan gender.

Pemilihan tema gender oleh Djumri Obeng dalam karya-karyanya berkaitan dengan isu sosial pada masa tersebut. Isu-isu kesetaraan gender mendominasi segala ranah di dunia pada tahun 1970-an hingga 1980-an. Hal tersebut tidak dapat dipisahkan dari perubahan sosial dan politik di Eropa dan Amerika. Pada tahun-tahun tersebut perempuan di Eropa Barat memiliki hak duduk dalam dewan perwakilan dan terlibat dalam pembuatan undang-undang. Sementara itu, walaupun kaum feminis kesetaraan hak di Amerika telah sukses memasukkan Amandemen Hak-hak yang Sama ke dalam Konstitusi melalui Kongres pada tahun 1920, usaha mengurangi opresi terhadap wanita giat dilakukan pada tahun 1960-an. Pada tahun 1961 Presiden John F. Kennedy mendirikan Commisssion on the Status of Women yang memberlakukan kebijakan kesetaraan pengupahan dan kebijakan hak-hak sipil yang mencegah diskriminasi (Tong, 2008,p. 35-36). Tahun 1979 Inggris mengalami perubahan sosial politik yang cukup signifikan ketika Margareth Teacher menjadi Perdana Menteri Inggris pertama. Di Indonesia pada tahun 1970-an sampai dengan 1980an pemerintah melibatkan PKK (Pembinaan Kesejahteraan Keluarga), yaitu sebuah organisasi kemasyarakatan yang beranggotakan perempuan untuk ikut berpartisipasi dalam pembangunan
(Murniati, 2004: 21). Pada tahun-tahun tersebut, gerakan emansipasi atau kesetaraan gender di Indonesia juga dipacu oleh perubahan pada sektor ekonomi dari bentuk agraris ke industri. Sektor pertanian memberi kontribusi terbesar bagi pendapatan Indonesia sebelum liberalisasi industri tahun 1980-an, sementara itu pada masa itu sektor manufaktur mulai menunjukkan peningkatan (Suyanto, 2010,p. 81). Gelombang industrialisasi memerlukan banyak pekerja, termasuk pekerja perempuan. Banyak perempuan di pedesaan berpindah ke kota sebagai pusat industri untuk bersaing dengan laki-laki mendapatkan bagian di bidang ekonomi. Keberadaan pekerja peerempuan telah menguatkan kesetaraan gender di bidang ekonomi, tetapi kesetaraan sosial belum didapatkan sepenuhnya oleh perempuan. Problematika lain yang berkaitan dengan fungsi perempuan mencuat pada masamasa itu, yaitu perdebatan tentang kuantitas peran perempuan dalam ruang publik dan rumah tangga (Subardini, Djati, \& Hakim, 2007,p.2). Sebagian masyarakat dapat menerima pekerja perempuan sebagai bagian dari industri, sebagian lagi menganggap keberadaan perempuan dalam industri sebatas pelengkap.

Seperti halnya karya sastra lainnya pada tahun 1970-an dan 1980-an yang banyak mengangkat tema emansipasi di ruang keluarga, karya Djumri Obeng tentang perempuan juga menampilkan persoalan perempuan di ruang keluarga dan ruang publik. Dengan kacamata seorang pria, Djumri Obeng memberikan opininya terhadap perempuan di masanya melalui karya-karyanya. Untuk mengetahui opini Djumri Obeng, tulisan ini menitikberatkan pada bagaimana citra perempuan pada tahun 1970 dan 1980-an dalam karya-karyanya, dan bagaimana pandangan Djumri Obeng terkait dengan marginalisasi perempuan masa itu. Sementara itu, tujuan penelitian ini adalah untuk mengkaji citra perempuan pada tahun 1970 dan 1980-an dalam karya-karya Djumri Obeng dan pandangan Djumri 
Obeng terkait dengan marginalisasi perempuan masa itu.

Beberapa penelitian sastra yang berhubungan dengan diskriminasi perlakuan terhadap wanita tahun 1970-an dan 1980-an pernah dilakukan, antara lain oleh Ni Nyoman Subardini dan kawankawan 2007. Buku yang diterbitkan Pusat Bahasa, Departemen Pendidikan Nasional, Jakarta ini berjudul Kedudukan Perempuan dalam Tiga Novel Indonesia Modern Tabun 1970-an. Buku ini memberikan ulasan terhadap tiga novel Indonesia yang terbit pada tahun 1970-an, yaitu Pada sebuab Kapal karya N. H. Dini, Pelabuban Hati karya Titis Basino, dan Astiti Rahayu karya Iskasiah Sumarto. Ketiga novel tersebut menyuarakan emansipasi wanita, yaitu perjuangan wanita dalam mengarungi hidup dengan bersikeras bertahan atas nama kepentingan dan harga diri mereka (Subardini, et al., 2007,p.124). Tokoh Sri dalam Pada sebuab Kapal bertahan atas pendiriannya dalam menentukan laki-laki pendamping hidupnya, tokoh Rani dalam Pelabuban Hati berusaha memepertahankan rumah tangganya ketika suaminya ingin kawinn lagi, dan tokoh Astiti dalam Astiti Rahayu yang selalu berusaha untuk bahagia dan tidak putus asa dengan setiap permasahan hidupnya. Emansispasi wanita yang digambarkan dalam ketiga novel tersebut adalah suatu bentuk pemertahanan diri akan persoalan hidup di tengah peran-peran mereka sebagai wanita, ibu dan istri. Para pengarangnya berusaha menunjukkan bahwa sebagai makhluk yang dianggap lemah, wanita mampu menunjukkan kekuatannya dengan cara mempertahankan prinsipnya. Melalui ketiga novel tersebut dapat diketahui juga bahwa perjuangan wanita untuk mendapatkan persamaan hak pada masa itu masih berkisar pada ruang keluarga.

Penelitian lainnya dilakukan oleh Amelia (2009) yang membandingkan ideologi feminisme karya sastra pada tahun 1970-an dan 2000-an. Hasil yang didapat dari penelitian tersebut bahwa ideologi feminisme yang tergambar dari tokoh karya sastra menunjukkan suatu perbedaan, yaitu tokoh-tokoh perempuan di angkatan 1970, dikatakan tidak terlalu menonjol dalam mempertahankan ideologi feminin mereka jika dibandingkan dengan tokoh perempuan angkatan 2000. Dengan kata lain, pola perlawanan terhadap perbedaan perlakuan gender lebih terlihat pada perempuan pada tahun 2000-an dibandingkan dengan perempuan tahun 1970-an.

\section{METODE}

Pengumpulan data menggunakan studi pustaka dengan teknik sampling yang diambil dari karya Djumri Obeng sebagai objek analisis. Sumber data berasal dari karya Djumri Obeng yang telah diterbitkan oleh media cetak, yaitu Minggu Merdeka, 14 Januari 1979 ("Bidadari di Tengah Hutan”), Minggu Merdeka, 1979 (“Anah”), dan Berita Minggu, 20--26 November 1984 ("Peni"). Pemilihan sampel berdasarkan karya-karya yang terdapat tokoh perempuan di dalamnya. Hal tersebut dilakukan untuk mendukung tujuan tulisan ini, yaitu mengetahui citra perempuan dalam cerita pendek karya Djumri Obeng.

Metode yang digunakan dalam penelitian ini adalah metode kualitatif, yaitu menafsirkan hasil analisis dalam bentuk deskripsi. Sesuai dengan paradigma positivisme yang dipelopori oleh Auguste Comte dan Emile Durkheim yang lebih menekankan fenomena sosial sebagai sesuatu yang yang memberikan pengaruh terhadap perilaku manusia (Moleong, 1994,p.31). Sementara itu, fenomenologis yang dipelopori oleh Max Weber berusaha lebih memahami perilaku manusia dari segi kerangka berpikir dan bertindaknya. Kedua paradigma tersebut sejalan dengan penelitian kualitatif yang mementingkan nilai-nilai sosial.

Tahap-tahapan dalam analisis dilakukan sebagai berikut. (1) menentukan bentuk-bentuk fokalisasi dan foklalisator dalam ketiga cerita pendek karya Djumri Obeng, (2) identifikasi bentuk fokalisasi yang berhubungan dengan gender, (3) 
analisis fokalisasi dalam tiga cerita pendek karya Djumri Obeng untuk menentukan citra perempuan pada tahun 1970-an dan 1980-an, (4) dan menyimpulkan pandangan Djumri Obeng terhadap perlakuan perbedaan gender berdasarkan fokalisai.

\section{HASIL DAN PEMBAHASAN}

Tiga cerita pendek karya Djumri Obeng yang akan dianalisis dalam tulisan ini adalah "Bidadari di Tengah Hutan (Merdeka, 14 Januari 1978), "Anah" (Minggu Merdeka, 1979), dan "Peni" (Berita Minggu, 20--26 November 1984). "Bidadari di Tengah Hutan" merupakan suatu cerita pendek berasal dari mitos yang berkembang dalam masyarakat Bugis yang tinggal di Kalimantan tentang burung hantu. Cerita pendek tersebut menceritakan seorang lelaki paruh baya bernama Daeng yang kesepian dan membutuhkan teman hidup. Dalam kesepiannya di tengah hutan, ia seringkali berteiak-teriak merindukan perempuan. Seekor burung hantu yang sedang terbang di sekitar daerah tersebut mendengar teriakannya. Mendengar teriakan Daeng yang menyedihkan, burung hantu kasihan dengan penderitaan Daeng. Ia kemudian mengubah wujudnya menjadi seorang wanita cantik. Daeng ternyata memiliki nafsu yang sangat luar biasa. Si burung hantu merasa kewalahan. Berkali-kali wanita jelmaan burung hantu itu meminta ampun pada Daeng. Akan tetapi, teriakan burung hantu itu tidak dihairaukan Deng. Karena tidak tahan melayani Daeng, wanita jadi-jadian tersebut melompat ke atas tebing dan berubah menjadi burung hantu kembali. Sejak saat itu burung hantu akan terbang jauh apabila orang-orang berteriak: "panggilkan daeng......panggilkan daeng!". Masyarakat memiliki kebiasaan mengusir burung hantu dengan kata-kata memanggil daeng.

Sementara otu, cerita pendek "Anah" bercerita tentang sosok Anah, seorang gadis miskin yang bekerja di sebuah rumah orang kaya. Anah senang bekerja di tempat majikannya itu karena menerima uang dua hari sekali. Suatu hari Anah disuruh mengerok tuannya. Ia tidak canggung lagi karena hal itu sudah keempat kalinya. Akan tetapi, hari itu ia diperkosa tuannya. Akibat perbuatan tuannya itu Anah berbadan dua. Suatu hari Anah diusir oleh polisi dari rumah majikannya dengan alasan tidak memiliki KTP. Di kampungnya, Anah tinggal dengan ibunya yang akhirnya meninggal karena tidak kuat menanggung malu. Pernah terlintas dalam pikiran Anah untuk menagih uang kepada majikannya bagi biaya persaliannnya kelak, tetapi ia takut pada polisi yang pernah mengusirnya. Ia juga pernah berusaha menggugurkan kandungannya. Akan tetapi, tidak ada dukun yang mampu menggungurkannya. Akhirnya Anah tinggal seorang diri di dalam gubuk di pinggir sawah yang bila malam hari hanya terlihat sebuah nyala pelita berkelap-kelip dari sana.

Cerita pendek ketiga yaitu "Peni" bercerita tentang seorang perempuan desa yang bekerja sebagai buruh tani yang berpenghasilan kecil. Sebagai seorang janda yang menanggung kehidupan seoarang anak, ia berniat mengadu nasibnya di kota besar utnuk mencari kehiduapan yang lebih baik sebagai pembantu rumah tangga. Suatu hari ia disuruh minum obat yang dapat membuatnya tidak sadarkan diri sehingga majikan laki-lakinya leluasa menodainya. Sebagai perempuan yang mengiginkan kebahagiaan, ia berniat meminta pertanggungjawaban majikannya untuk menikahimua, tetapi ancaman majikannya untuk memanggilkan polisi membuatnya takut. Ia akhirnya pulang kampung dengan membawa uang cukup banyak sehingga ia dapat hidup cukup selama dua bulan di kampung dengan ibu dan anaknya. Namun pada bulan ketiga, Peni harus kembali pada pekerjaan sebagai buruh tani dengan penghasilan yang kecil karena uang dari majikannya sudah habis. Semetara itu, para tengkulak yang membeli hasil bumi desa Peni selalu kaya raya. Salah satu tengkulak tersebut adalah bekas majikan Peni. 


\section{Penokohan}

Daeng sebagai tokoh utama dalam cerpen "Bidadari di Tengah Hutan" digambarkan sebagai seorang laki-laki yang berumur lima puluh tahun yang belum menikah. Sebagai lelaki normal, Daeng berkeinginan memiliki seorang istri. Akan tetapi, sampai sampai pada usianya yang kelima puluh dia masih tetap hidup membujang. Ia menyibukkan dirinya dengan menjadi pedagang kelapa di sepanjang ulu sungai Mahakam.

Lelaki yang mendayung perahu sepanjang hari itu bernama Daeng. Dia berumur lima puluh tahun dan menghabiskan hampir separuh dari usianya sebagai pedagang kelapa yang menawarkan dagangannya kepada penduduk yang yang berdiam di sepanjang hulu Sungai Mahakam. Sebagai Mahkluk Tuhan yang masih normal, lelaki itu ingin sekali mendapatkan istri yang cantik..... (MM, 14 Januari 1979).

Tokoh Daeng digambarkan sebagai seorang laki-laki yang hampir putus asa untuk mendapatkan pasangan hidup karena di umurnya yang sudah separuh baya belum juga mendapatkan istri. Ia akhirnya menyibukkan diri dengan pekerjaannya. Dengan menekuni pekerjaannya, ia berharap bahwa suatu ketika ia akan mendapat istri.

Tokoh kedua, yaitu wanita jelmaan burung hantu merasa kasihan melihat penderitaan Daeng karena memendam rasa kesepian yang luar biasa. Ia berniat menolong Daeng untuk meringankan penderitaan Daeng. Akhirnya ia merubah wujudnya menjadi seorang wanita.

Teriakan lelaki itu terdengar oleh seekor burung hantu yang sedang bertengger di atas pohon kayu besi. Binatang itu merasa kasihan melihat betapa tersiksanya $\mathrm{Si}$ Daeng diombang-ambingkan oleh kesepian birahinya. Selanjutnya terjadilah keajaiban di malam sunyi dan gelap itu. Sang unggas yang tadinya tidak lebih dari seekor hewan tiba-tiba menjelma menjadi wanita cantik yang berkulit kuning langsat dan yang berambut panjang terurai. Kecantikannya bagai seorang bidadari (MM, 14 Januari 1979).

Sementara itu, tokoh Anah dalam cerita pendek "Anah" adalah seorang gadis dusun, miskin, dan buta huruf. Ia berkeinginan mengubah nasib agar tidak seperti orangtuanya. Satu-satunya pekerjaan yang dapat dilakukannya adalah menjadi pembantu rumah tangga. Ia kemudian menjadi seorang pembantu di rumah orang kaya di kota.

Anah anak orang kampung. Tidak bisa membaca dan tidak pula bisa menulis. Dia bukan gadis yang cantik, tapi bukan pula perawan yang jelek. Kalau saja dia mau punya laki sudah tiga orang yang bersedia menjadikannya sebagai istri. Tapi Anah tidak mau. Sebab ketiga lelaki tadi adalah petani desa yang seperti juga ayahnya tidak memiliki sawah. Anah tidak ingin mewarisi nasib seperti ayahnya. Karena itu dia lalu pergi ke kota. Biasa bekerja sebagai babu. Cuma itu yang mampu dilakukannya. Lain tidak ( $M M$, 1979).

Selain itu tokoh Anah juga digambarkan sebagai tokoh yang lugu. Keluguannya menyebabkan Anah tidak curiga ketika tuannya memerintahkan Anah untuk mengeroki dirinya. Akan tetapi, Anah justru diperkosa hingga hamil.

Dan di kamar itu majikannya sudah menelungkupkan badan. Dan begitu Anah duduk disampingnya, anak perawan dusun itu terus dipeluk, terus mulutnya ditutup, terus dibaringkan, terus ditelanjangi, terus...terus... terus... $(M M, 1979)$.

Selain lugu, Anah juga tokoh yang pasrah. Ia tidak pernah berniat membalas 
perlakuan orang-orang yang menganiayanya. Satu-satunya yang dia inginkan hanyalah biaya persalinan dan uang untuk mengontrak rumah agar hidupnya lebih baik.

Anah bermaksud untuk kembali ke kota, meminta uang lagi kepada bekas majikannya supaya mau mengurus biaya kelahiran anak yang ada dikandungnya atau setidaktidaknya mengontrakkannya rumah di kota supaya dia dan ibunya bebas dari himpitan batin yang mereka derita selama ini. Tapi bila Polisi yang mengancamnya dulu terbayang dibenak dan dimatanya, maksud itu pun dibatalkannya hingga akhirnya dia merasa putus asa dan berusaha menggugurkan bayi dalam perut itu (MM, 1979).

Tokoh kedua dalam cerita pendek Anah adalah majikan laki-laki. Awalnya, majikan Anah digambarkan sebagai tuan yang baik hati, berkulit kuning, bertubuh gemuk, dan bermata sipit. Ia sering mengajak bicara dan memberi uang Anah, sehingga Anah akhirnya tidak takut pada majikan laki-lakinya tersebut.

Dua hari sekali Anah sering diberi duit. Katanya buat jajan. Anah gembira. Duit itu disimpannya saja dalam celengan tanah. Dia berencana kalau sudah lebaran dan mau pulang mudik baru celengan itu dibukanaya $(M M, 1979)$.

Namun, kekayaan yang dimiliki sang majikan ternyata dipergunakan untuk memanipulasi keluguan Anah. Setelah Anah tidak lagi takut dengannya ia malah membalasnya dengan menghamili Anah.

Tokoh ketiga adalah seorang polisi yang disuruh oleh majikan Anah untuk mengusir Anah. Polisi ini digambarkan sebagai seorang yang berasal dari suku yang sama dengan Anah yang seharusnya memihak Anah. Anamun, pada kenyataaannya ia berpihak pada majikan yang telah memberinya uang.
Yang mengusirnya bukan toke besar dan bukan pula nyonya besar. Tapi adalah polisi yang juga memiliki kulit sawo matang sepereti Anah. Alasannya mudah saja, Anah belum punya KTP $(M M, 1979)$.

Cerita pendek "Peni" memiliki tema yang sama dengan Anah, yaitu tentang perempuan desa miskin yang harus menjadi pembantu rumah tangga di kota untuk mencari uang buat kehidupan keluarganya. Tokoh Peni digambarkan sebagai seorang janda muda miskin yang menanggung hidup seorang ibu dan anak perempuannya. Ia harus pergi ke kota, meninggalka anak perempuan dan ibunya untuk mencari uang lebih bagi kehidupann mereka.

Dua kali dia menangis sambil memeluk anaknya. "Kamu tinggal sama nenek. Ibu ke kota mencarikan makan." Gadis itu terpaku sambil menatap wajah neneknya tempat dia ditititpkan. (BM, 1984).

Sebetulnya Peni sudah memiliki pekerjaan pad saat ia tinggal di desa, yaitu sebagai buruh pembersih rumput di sawah dengan upah sedikit yang hanya cukup untuk makan sederhana. Namun, Peni merasa bahwa kehidupan keluarganyanya tidak cukup hanya makan saja, keluarganya juga memerlukan pakaian dan sedikit perhiasan untuk anaknya. Untuk alasan tersebut, Peni bersikeras meninggalkan desanya dan menjadi pembantu rumah tangga di rumah Toke Tan Kim Swie atau Tono Karso.

Lama-lama Peni tahu juga bahwa hidup ini tidak cukup hanya dengan memenuhi lambung dengan butirbutir nasi, ikan teri, dan ditambah dengan sayur jantung pisang. Lebih dari itu, Peni juha memerlukan pakaian dan kalau bisa sedikit demi sedikit mengumpulkan uang untuk membeli dua gram emas yang bakal disangkutkan di kuping anaknya (BM, 1984). 
Namun, Peni tetaplah seorang perempuan desa yang lugu yang masih mudah untuk diperdaya. Ia tidak tahu bahw a majikan laki-lakinya telah merencanakan sesuatu yang merugikan dirinya.

Peni anak desa. Lahir di desa dan besar di desa. Dia mengira tablet yang diberikan padanya jauh lebih baik dari tablet yang dibelinya di warung dengan dua puluh lima rupiah. Dia tidak tahu bahwa denga pil itu kepalanya bakal pusing, darahnya bakal panas, matany abakal berkunang-kunang, dan dia pun tidak tahu bahwa bahwa denga tablet itu pula musnah kesepiannya sebagai janda Kimian yang laikinya meninggal di tengah kali Citarum tiga tahun yang lalu $(B M, 1984)$.

Tokoh kedua dalam cerita pendek "Peni" adalah Tono Karso, majikan laki-laki Peni. Tono Karso digambarkan sebagai orang kaya yang licik. Ia memanfaatkan leluguan Peni sebagai perempuan desa untuk keuntungannya sendiri. ia juga memanfaatkan kekayaannya untuk membujuk Peni untuk menuruti kemauannya.

"Kamu bisa ngerok, ya?" Peni mau bilang tidak bisa, tapi hati kecilnya tetap memerintahkan untuk melakukan, sebab Tuan Tono Karso sudah berjanji mau ngasih duit seribu. Dan duit itu cukup menambah tabungan untuk membeli emas dua gram buat digantungkan di kuping anaknya (BM, 1984).

Tokoh Tono Karso selain licik juga jahat dan tidak bertanggung jawab. Setelah mengetahui Peni hamil, ia segera menyuruh pulang ke desanya. Tono Karso bahkan mengancam Peni memanggil polisi, ketika Peni meminta untuk dinikahi, walaupun sebagai istri simpanan.

\section{Citra Perempuan}

Untuk mengetahui citra perempuan dalam tiga cerita pendek "Bidadari di tengah Hutan", "Anah", dan "Peni” karya Djumri Obeng, diperlukan teori fokalisasi. Teori ini bekerja dengan cara melihat pandangan fokalisator tentang tokoh perempuan dalam tiga cerita pendek tersebut.

Fokalisasi intern dalam ceita pendek "Bidadari di tengah Hutan" dilakukan oleh tokoh Daeng untuk menggambarkan wanita ideal bagi dirinya. Penggambaran perempuan cantik yang ada dalam bayangan Daeng adalah berkulit kuning dan berambut panjang.

Lelaki itu mulai membayangkan. Otaknya mengkhayal seorang perempuan cantik yang berkulit kuning langsat yang berambut panjang terurai (MM, 14 Januari 1979).

Melalui khayalan Daeng tentang wanita cantik diketahui bahwa seorang perempuan cantik itu secara fisik harus memiliki kulit kuning langsat dan berambut panjang mengurai. Sementara itu, fokalisator ekstern, yaitu pencerita menguatkan pemikiran Daeng sebagai fokalisator intern tentang gambaran seorang perempuan cantik. Seolah mengiyakan bahwa perempuan cantik adalah yang berkulit putih dan beramabut panjang, burung hantu kemudian menjelma menjadi seorang wanita cantik seperti bayangan Daeng, yaitu berkulit kuning langsat dan berambut panjang, ia melayani Daeng. Bahkan, perempuan jadi-jadian tersebut bersedia melayani nafsu syahwat Daeng.

"Jangan takut," ujar perempuan itu, lalu meneruskan. "Saya datang kemari sengaja untuk menemanimu. Siapa nama Tuan?" Daeng belum menjawab. Dia masih terpaku hingga perempuan tersebut sudah duduk di sampingnnya ( $M M, 14$ Januari 1979).

Kutipan tersebut menerangkan bahwa keberadaan perempuan hanyalah untuk melayani laki-laki. Oleh karena tidak ditemukan perempuan yang sesuai dengan 
keinginan Daeng, yaitu yang cantik, putih dan berambut panjang, kemudian diciptakanlah perempuan dari seekor burung hantu untuk melayani Daeng.

Dalam pandangan feminis bahwa gambaran wanita cantik yang harus berambut panjang dan berkulit putih merupakan bentuk marginalisasi terhadap wanita selain memiliki ciri-ciri tersebut. Marginalisasi tersebut kemudian melahirkan stereotip bahwa wanita yang tidak putih dan berambut panjang tidak cantik. Selain itu, penyerahan diri perempuan terhadap laki-laki dalam pandangan feminis merupakan suatu bentuk dominasi kaum laki-laki terhadap perempuan. Mary Wollstonecraft dalam $\underline{A}$ Vindication of the Rights of Woman (1792) menyatakan bahwa perempuan seharusnya menjadi manusia secara utuh (Tong, 2008,p. 22). Lebih lanjut ia menyatakan bahwa perempuan bukanlah alat untuk kebahagiaan orang lain. Sebaliknya, perempuan adalah individu yang berhak menentukan nasibnya sendiri. Fokalisasi yang ditunjukkan oleh tokoh Daeng memperlihatkan dominasi laki-laki terhadap perempuan untuk menuruti segala kemauan laki-laki.

Fokalisasi intern dalam cerita pendek "Anah" oleh fokalisator majikan laki-laki terhadap Anah, yaitu menggangap Anah seorang gadis lugu yang dapat ditipu dan dipermainkan. Majikan laki-laki Anah sengaja mendekati dan merayu Anah untuk memanfaatkan gadis tersebut.

"Apa kamu tidak punya pikiran mau punya suami?"

"Akh, tidak tuan."

"Masa?"

"Betul, Tuan."

"Kalau sama saya, apa Anah mau?"

"Akh, tuan ini macam-macam saja."

" Lho, ini bukan macam-macam. Betul-betul." (MM, 1979).

Pada dasarnya kebaikan-kebaikan yang dilakukan oleh majikan laki-laki tersebut hanyalah kedok untuk memanfaatkan
Anah. Sejak awal majikan laki-laki berusaha mendapatkan kepercayaan Anah, sehingga Anah tidak takut padanya pada saat disuruh mengerok majikan laki-lakinya.

Anah sekarang tidak takut. Dia tidak punya curiga, sebab sudah empat kali dia disuruh ngerok, tak pernah tokenya itu berbuat yang sembrono. Karena itu dia lalu masuk ke kamar. Dan di kamar itu majikannya sudah menelungkupkan badan. Dan begitu Anah duduk di sampinganya, anak perawan dusun itu terus dipeluk, terus mulutmya ditutup, terus dibaringkan, terus ditelanjangi, terus...., terus...., dan bila kemudian harinya Anah berbadan dua. Anah pun diusir dari rumah itu $(M M, 1979)$.

Sebagai seorang gadis lugu yang mudah diperdaya dengan sedikit kebaikan, Anah akhirnya jatuh dalam tipu daya yang kemudian disesalinya. Setelah Anah dijadikan pemuas nafsu sehingga hamil, Anah justru diusir tanpa ada pertanggungjawaban dari majikannya terhadap masa depan Anah. Pengusiran yang dilakukan oleh majikannya semakin menunjukkan bahwa majikannya tidak memilki itikad baik dan hanya memanfaatkan keluguan Anah.

Fokalisator berikutnya adalah polisi yang mengusir Anah dari rumah majikannya. Perilaku yang ditunjukkan oleh polisi tersebut menunjukkan bahwa ia hanya berpihak kepada orang yang memberinya keuntungan. Kalimat yang menunjukkan bahwa ia memiliki kulit sawo matang yang sama dengan Anah, artinya satu suku atau bangsa yang seharusnya membela Anah justru membela suku atau bangsa lain yang lebih memberinya keuntungan. Bahkan, polisi tersebut justru mengintimasi Anah agar tutup mulut atas segala peristiwa di rumah majikannya tersebut.

"Pokoknya kamu mesti taat sama perintah Polisi." Anah mengalah. Mengalah seratus persen. Dan untuk kekalahannya itu dia dilarang buka mulut. Dilarang menceritakan tentang perbuatan toke besar, 
dilarang menceritakan tentang dirinya yang dipanggil Polisi dan untuk itu Anah menerima imbalan lima puluh ribu rupiah dari bekas majikannya $(M M, 1979)$.

Kedudukan Anah sebagai perempuan desa yang miskin digunakan oleh majikan laki-laki untuk mengintimidasai Anah. Intimidasai yang dilakukan pada Anah bermaksud untuk kepentingan pribadi majikan laki-laki. Bahkan, untuk menguatkan intimidasainya, majikan lakilaki meminta polisi untuk membantu menyakinkan Anah bahwa Anah sebagai perempuan desa yang miskin tidak memiliki peran apa-apa selain menuruti perintah majikannya. Selain itu, peran Anah sebagai pembantu rumah tangga dianggap sebagai masyarakat kelas sosial rendah yang dapat dimanfaatkan oleh majikan yang menganggap dirinya memiliki kelas sosial lebih tinggi.

Dalam pandangan feminis perlakuan tidak adil terhadap perempuan miskin dan tidak berpendidikan, seperti Anah dianggap sebagai pelecehan. Apalagi perbuatan asusila yang dilakukan majikan laki-laki terhadap Anah tanpa diikuti oleh rasa tanggung jawab merupakan bukti pelecehan seksual. Kemiskinan dan keluguan perempuan desa dianggap sebagai alasan untuk melakukan pelecehan terhadap Anah. Perlakuan perbedaan gender dalam cerita pendek "Anah" meliputi beberapa, yaitu marginalisasi, subordinasi, dan kekerasan. Marginalisasi yang dilakukan masyarakat pada waktu itu yang diwakili majikan lakilaki adalah anggapan bahwa perempuan desa yang tidak berpendidikan hanya dapat bekerja di sektor domestik sebagai pembantu rumah tangga. Dengan menjadi pembantu di rumahnya, majikan laki-laki dapat melakukan subordinasi bahwa kedudukan Anah, sebagai pembantu rumah tangga lebih rendah daripada majikan sehingga majikan dapat melakukan apa saja terhadap Anah. Oleh karena anggapan subordinat tersebut, majikan mengganggap dapat memanfaatkan Anah untuk melampiaskan nafsu syahwatnya. Tindakan tersebut sebagai bentuk dari tindak kekerasan. Ditambah lagi tindak kekerasan yang diterima Anah adalah pengusiran yang dilakukan oleh oknum polisi atas permintaan majikan Anah. Tindak kekerasan dibanguan atas sistem kekuasaan berdasarkan oposisi biner laki-laki dan perempuan, yaitu biner patriarki memosisikan perempuan sebagai subordinat (Murniati, 2004,p.221)

Fokalisasi intern dalam cerita pendek "Peni" yang dilakukan tokoh Tono Karso terhadap tokoh perempuan, yaitu Peni menggambarkan pandangan Tono Karso bahwa perempuan desa yang miskin dapat dipaksa untuk menuruti kemauannya dengan iming-iming imbalan uang yang diperlukan oleh Peni.

"Kamu bisa ngerok ya?" Peni mau bilang tidak bisa, tapi hati kecilnya tetap memerintahkan untuk melakukan, sebab tuan Tono Karso sudah berjanji mau ngasih duit seribu. Dan duit itu cukup menambah tabungan untuk membeli emas dua gram buat digantungkan di kedua kuping anaknya (BM, 1984).

Kelemahan Peni sebagai orang miskin dan bodoh dijadikan sebagai senjata Tuan Ton Karso untuk memanfaatkan Peni dengan cara memanipulasinya. Ketidaktahuan Peni sebagai perempuan desa yang tidak berpendidikan juga dimanfaatkan untuk menipu dan menjerumuskan Peni untuk kepentingan Tuan Tono Karso sendiri.

Apalagi setelah Tuan Tono Karso memberi sebutir tablet kepada Peni sambil bilang begini, "Kalau kamu mau gemuk coba minum pil ini," (BM, 1984).

Kutipan tersebut menjelaskan bahwa Tuan Tono Karso sengaja menjerumuskan Peni dengan menipunya untuk meminum obat agar sehat yang sebenarnya adalah obat perangsang. Dengan demikian, sangat mudah bagi Tuan Tono Karso untuk menodai Peni.

Selain itu, tokoh Peni yang miskin dalam pandangan Tono Karso tidak berhak 
mendapat perlakuan yang sama dengan perempuan lain. Setelah dinodai Peni malah diusir pulang ke kampunganya. Sebagai imbalannya Tuan Tono Karso hanya memberi uang tanpa tanggung jawab menikahi Peni. Sebagai seorang pembantu rumah tangga dalam pandangan Tuan Tono Karso, Peni hanyalah perempuan dari golongan yang lebih rendah darinya sehingga dapat diperlakukan sebagai pelacur yang hanya diberi imbalan uang. Ia bahkan menggertak Peni akan memanggil polisi apabila Peni meminta untuk dinikahi.

\begin{abstract}
"Ini uang tujuh puluh lima ribu.buru-buru kamu pulang ke Batujaya.” (BM, 1984).

Dengan mengeluarkan satu kalimat saja, berhasillah Tono Karso membuat wanita itu gemetar dan ketakutan: Kalau kamu keras kepala, terpaksa kubawakan polisi ( $B M$, 1984).
\end{abstract}

Sama halnya dengan tokoh Anah dalam cerita "Anah", tokoh Peni dalam cerita "Peni" mengalami penindasan seksual dari majikan laki-laki yang menganggap diri mereka memiliki kelas sosial lebih tinggi dari pembantunya sehingga mereka dapat atau berhak menindas pembantunya. Pemikiran Tuan Tono Karso mengakibatkan beberapa perlakuan perbedaan gender terhadap Peni, yaitu marginalisasi, subordinasi, dan kekerasan.

Dalam pandangan kritikus sastra feminis etnik, pemikiran majikan laki-laki (dalam cerita "Anah" dan "Peni") digolongkan dalam diskriminasi seksual dan rasial. Tokoh Anah dan Peni tidak hanya mengalami penindasan secara seksual juga mengalami penindasan dari kelompok lain yang merasa berasal dari golongan sosial lebih tinggi. Perbedaan etnik, seperti halnya gender diajarkan kepada seseorang sejak dia masih kecil (Djajanegara, 2000,p.38). Kesukuan mengacu kepada orientasi budaya yang dibentuk oleh tradisi serta pengalaman yang dibentuk suku tersebut. Dalam cerita pendek "Anah dan "Peni" pembetukan budaya kesukuan yang terjadi adalah bahwa majikan adalah berasal dari golongan sosial yang lebih tinggi dari pembantunya. Hal tersebut semakin diperkuat dalam kedua cerita pendek tersebut bahwa majikan yang berasal dari etnis Cina.

\section{Pandangan Djumri Obeng terhadap Marginalisasi Perempuan}

Tiga cerita pendek karya Djumri Obeng, yaitu "Bidadari di Tengah Hutan", "Anah", dan "Peni" memberikan gambaran yang cukup terhadap marginalisasi perempuan pada tahun 1970-an san 1980-an. Pemarginalan terhadap perempuan dilakukan melalui tiga ruang, yaitu sosial, ekonomi, dan stereotip. Pemarginalan secara sosial dan ekonomi terjadi dalam cerpen "Anah" dan "Peni", sedangkan pemarginalan secara stereotip tergambar dalam cerita "Bidadari di Tengah Hutan".

Anah dan Peni sebagai tokoh utama dalam cerpen Djumri Obeng digambarkan sebagai perempuan yang mengalami maginalisasi dalam ruang sosial dan ekonomi. Kedua tokoh tersebut tidak memiliki pendidikan dan kekayaan untuk mendukung kedudukan status sosial, sehingga mereka mudah dipermainkan. Status sosial mereka merupakan wujud marginalisasi masyarakat pada masa itu untuk mengukuhkan kedudukan masyarakat kelas sosial ekonomi lebih tinggi. Marginalisasi yang dilakukan masyarakat dalam cerita pendek "Anah" dan "Peni" menyebabkan perempuan hanya mampu melakukan pekerjaan domestik, yaitu sebagai buruh di sawah atau sebagai pembantu rumah tangga. Pemiskinan tersebut kemudian dimanfaatkan untuk mengambil keuntungan dari perempuan dan membenarkan tindakan kejahatan mereka terhadap perempuan. Dengan demikian, perempuan miskin tidak memiliki kekuatan untuk melakukan penawaran atas kerugian mereka yang disebabkan oleh tindakan oknum masyarakat yang lebih kaya. Hal itu terjadi kepada Anah dan Peni, perempuan miskin yang dinodai 
majikannnya dan tidak mendapatkan kompensasi atas kerugian mereka. Bahkan, lebih lanjut Djumri Obeng menunjukkan dalam kedua cerita pendek tersebut bahwa perempuan dengan status ekonomi rendah identik sebagai orang yang bersalah. Orangorang kaya mengancam perempuan status ekonomi rendah dan tidak berpendidikan dengan cara memanggil polisi. Hal tersebut dituangkan oleh Djumri Obeng dalam karyanya "Anah" dan "Peni".

Pemarginalan perempuan secara stereotip tertuang dalam cerita "Bidadari di Tengah Hutan”. Cerita pendek tersebut menggambarkan pemikiran laki-laki dan masyarakat yang menganggap bahwa peran perempuan adalah untuk melayani nafsu syahwat laki-laki. Hal tersebut sangat bertentangan dengan pendapat Mary Wollstonecraft dalam A Vindication of the Rights of Woman (1792) menyatakan bahwa perempuan seharusnya menjadi manusia secara utuh (Tong, 2008,p.22) karena perempuan bukanlah alat untuk kebahagiaan orang lain. Perempuan adalah individu yang berhak menentukan nasibnya sendiri. Dalam cerita "Bidadari di Tengah Hutan" Djumri Obeng seolah mengkritik pemikiran masyarakat yang tertuang dalam mitos tentang burung hantu dan Daeng yang isinya ternyata melecehkan perempuan. Bahkan, setelah kembali menjadi burung hantu, masyarakat masih mengusirnya dengan cara menyebut nama Daeng berulang-ulang untuk mengusir burung hantu tersebut yang mereka yakini sebagai binatang tunggangan setan. Pandangan Djumri Obeng terhadap marginalisasi perempuan terlihat melalui fokalisasi tokoh-tokohnya, terutama tokohtokoh yang menjadi faktor negatif perlawanan terhadap patriarki, yaitu Daeng dan masyarakat yang memercayai mitos burung hantu menjadi wanita untuk menjadi pemuas nafsu laki-laki. Eksploitasi perempuan dalam masyarakat pada masa itu seakan-akan merupakan hal yang lumrah, apalagi perempuan tersebut hanyalah perempuan jadi-jadian jelmaan burung hantu.
Djumri Obeng dalam ketiga karya cerita pendeknya mencoba menggambarkan kebobrokan pemikiran masyarakat pada masa itu yang meminggirkan kedudukan perempuan melalui sosial, ekononomi, dan konsep stereotip yang tergambar melalui fokalisasi tokoh yang menjadi faktor negatif meresensi pemarginalan perempuan, yaitu tokoh-tokoh yang memperlihatkan dukungan terhadap pemarginalan perempuan dalam fokalisasinya.

\section{SIMPULAN}

Citra perempuan tahun 1970-an dan 1980an tergambar melalui tiga cerita pendek Djumri Obeng, yaitu "Bidadari di Tengah Hutan", "Anah", dan "Peni". Ketiga cerita pendek tersebut mengungkapkan marginalisasi masyarakat terhadap perempuan pada masa tersebut melalui tiga ruang, yaitu sosial, ekonomi, dan stereotip. Secara sosial, perempuan dengan tingkat pendidikan rendah adalah sasaran penindasan karena dianggap tidak memiliki kemampuan untuk melawan yang disebabkan sedikitnya pengetahuan yang mereka miliki. Sementara itu, perempuan dengan tingkat ekonomi rendah dianggap dapat dibayar sebagai kompensasi atas kerugian mereka akibat ulah oknum masyarakat yang mengambil keuntungan dari mereka. Anah dan Peni adalah contoh perempuan dengan tingkat ekonomi rendah yang hanya diberi uang setelah dihamili majikannya. Marginalisasi stereotip terjadi pada tokoh perempuan dalam cerita pendek "Bidadari di Tengah Hutan" yang menganggap bahwa perempuan tercipta hanya untuk melayani laki-laki. Anggapan tersebut tumbuh subur ditambah dengan anggapan tentang standar kecantikan perempuan yang menjadi idaman laki-laki. Hal itu semakin meyakinkan masyarakat-termasuk para perempuan--bahwa hidup perempuan ditujukan untuk para laki-laki.

Melalui ketiga cerita pendek tersebut mengungkapkan, Djumri Obeng mengungkapkan citra perempuan yang termarginalisasi pada tahun-tahun 1970-an dan 1980-an karena rendahnya kesadaran 
akan pentingnya penolakan terhadap pemarginalan perempuan dengan alasan apapun. Selain mengungkap pemarginalan perempuan, Djumri Obeng juga menggambarkan kebobrokan masyarakat dan oknum yang memarginalkan tokoh perempuan dalam cerpen-cerpennya dengan alasan status sosial dan ekonomi.

\section{DAFTAR RUJUKAN}

Amelia, K. (2009). Ideologi feminisme dalam karya sastra angkatan 1970 dan angkatan 2010. Universitas Sumatera Utara Medan.

Djajanegara, S. (2000). Kritik sastra feminis. (P. P. G. P. Utama, Ed.). Jakarta.

Luxembug, J. V., Bal, M., \& Westteijn, W. (1991). Tentang sastra. Jakarta: Intermassa.

Moleong, L. (1994). Metodologi penelitian kualitatif. Bandung: PT Remaja Rosdakarya.
Murniati, N. (2004a). Getar gender buku kedua. (Y. I. Tera, Ed.). Magelang.

Murniati, N. (2004b). Getar gender buku pertama. Magelang: Yayasan Ikatan Tera.

Ratna, N. K. (2008). Teori, metode, dan teknik penelitian sastra. Yogyakarta: Pustaka Pelajar.

Subardini, N. N., Djati, W., \& Hakim, Z. (2007). Kedudukan perempuan dalam tiga novel indonesia modern tahun 1970-an. Jakarta: Pusat Bahasa.

Suyanto. (2010). Perkembangan Bisnis dan Industri Indonesia 1970--2010: Sebuah Tinjauan Makroekonomi. Humaniora, 4(1).

Tong, R. P. (2008). Feminist thought pengantar paling komprehensif kepada arus utama pemikiran feminis. Yogyakarta: Jalasutra. 